\title{
A History of the Native Woodlands of Scotland, 1500-1920
}





\title{
A History of the Native Woodlands of Scotland, 1500-1920
}

\author{
T. C. Smout, Alan R. MacDonald \\ and
}

Fiona Watson 
(C) T. C. Smout, Alan R. MacDonald and Fiona Watson, 2005, 2007

First published in hardback in 2005 by

Edinburgh University Press Ltd

22, George Square, Edinburgh

This paperback edition 2007

Typeset in Minion and Gill Sans

by Pioneer Associates, Perthshire,

with corrections by Servis Filmsetting Ltd, Manchester, 2007 and printed and bound in Spain by

GraphyCems, Spain

A CIP record for this book is available from the British Library

ISBN 978 o 748632947 (paperback)

The right of T. C. Smout, Alan R. MacDonald and Fiona Watson to be identified as authors of this work

has been asserted in accordance with

the Copyright, Designs and Patents Act 1988.

Published with the support of the

Edinburgh University Scholarly Publishing Initiatives Fund. 